\title{
Neutered Indicator
}

National Cancer Institute

\section{Source}

National Cancer Institute. Neutered Indicator. NCI Thesaurus. Code C158349.

An indication as to whether the animal(s) has been neutered. 